\title{
Integration of carbohydrate and lipid metabolism in skeletal muscle during postnatal development
}

\author{
R. A. J. CHALLISS, P. FERRÉ $\left({ }^{1}\right)\left({ }^{*}\right)$ \\ Department of Pharmacology and Therapeutics, Medical Sciences Building \\ University of Leicester, University Road, Leicester LE1 7RH, U.K. \\ (*) Centre de Recherches sur la Nutrition, C.N.R.S. \\ 9. rue J. Hetzel, 92190 Meudon-Bellevue, France.
}

Summary. In the adult, muscle metabolism represents a large drain of energetic substrates. The newborn has to provide additional energy to its muscles in order to ensure a rapid growth. However, since during the neonatal period the newborn is fed with a high-fat low-carbohydrate diet, i.e., milk, the newborn must also spare glucose for organs which are obligatory glucose consumers such as the brain. Thus, regulation of energetic substrate utilisation by muscle is of upmost importance for postnatal metabolic homeotasis.

In the human, fibre types at birth can already be histochemically classified as adult types and the proportional distributions of each fibre-type approximate those seen in the adult. On the other hand, glycolytic and oxidative maximal enzyme activities are lower than adult levels.

In the rat, the capacity for glucose utilisation in muscles is low at birth, reaches a peak at weaning and subsequently decreases. During the suckling period, the concentration of lipid-derived substrates is high as well as the muscle capacity for their oxidation; moreover, insulin concentration is low and insulin sensitivity of muscle glucose utilization is also reduced. Thus, during the suckling period, fuel availibility and insulin concentrations, as well as tissue sensitivity towards the hormone, favour the limitation of glucose utilisation by skeletal muscles.

\section{Introduction.}

After birth, the neonate must undergo a multitude of physiological adaptations to its extrauterine environment. In utero, there is a constant substrate supply which is regulated by parental metabolism. In contrast, the neonate must adapt to intermittent periods of feeding by controlling mobilization and utilization of carbohydrates, lipids and protein to meet demands during post-absorptive periods.

In addition, fuels available to the neonate change dramatically after parturition ; in utero, carbohydrate and amino acids have been supplied for anabolic and catabolic needs, whereas the neonate receives a high-lipid diet with a smaller carbohydrate component. Since brain, which in the newborn represents a higher percentage of body mass [the brain of the human neonate represents $12 \%$ of the

() To whom correspondence should be sent. 
body mass compared to $2.5 \%$ in the adult (Dobbing \& Sands, 1973)], is an obligatory glucose consumer, the newborn has to adapt itself to this new situation. This is achieved in two ways: at first the newborn can activate its endogenous glucose production. It is indeed well established that the gluconeogenic pathway is active after birth in the human (Kalhan, Savin \& Adam, 1976 ; Bier et al., 1977 ; Denne and Kalhan, 1986) and in other species (Girard and Ferré, $1982)$; the newborn could spare glucose in tissues able to utilise alternative lipid or lipid-derived substrates. It has been shown for instance that ketone bodies are quantitatively important substrates for the neonatal brain (Settergren, Linblad and Persson, 1976), being used catabolically to reduce the requirement for glucose (Kraus, Schlenker and Schwedesky, 1974 ; Adam et al., 1975) and anabolically as lipid precursors (Patel et al., 1975). It has been shown in the adult man that after the brain, the muscles, even in the resting state, represent quantitatively the most important mass of tissue for glucose utilisation (De Fronzo et al., 1981).

In other species such as the rat, in which glucose consumption by the brain represents a minor drain on glucose metabolism, muscle can even represent the most important mass of tissue consuming glucose (Ferré et al., 1985). Therefore, regulation of substrate utilisation by muscle is of upmost importance for postnatal metabolic homeostasis.

This review will discuss the integration of carbohydrate and lipid metabolism by muscle in the neonate.

\section{Fiber types and biochemical differentiation.}

In the human foetus up to the 30th week of gestation, skeletal muscle consists largely of undifferentiated fibres (Tomanek and Colling-Saltin, 1977; Colling-Saltin, 1978a) ; however, between 31 weeks of gestation and parturition, rapid differentiation of fibres occurs, such that at birth over $80 \%$ of the muscle fibres can be histochemically classified (Brooke and Kaiser, 1970) as type I, Ila or $\mathrm{Ilb}$, and the proportional distributions of each fibre-type approximate those seen in the adult (Sillau and Banchero, 1977; Colling-Saltin, 1978a). This suggests that post-natal growth of skeletal muscle is mainly due to hypertrophy of existing fibres (Goldspink, 1970).

At birth, muscle glycogen and triacylglycerol content are similar to those seen in the adult muscle (Colling-Saltin, 1978b). On the other hand, glycolytic and oxidative maximal enzyme activities are lower than adult levels; thus, in human skeletal muscle sampled shortly after birth, 6 -phosphofructokinase and succinate dehydrogenase activities are $50 \%$ and $40 \%$ respectively of adult values (Colling-Saltin, 1978b).

Similar findings have been reported in animal experiments; a comparison of enzyme activities in heart, diaphragm and quadriceps muscle of adult and newborn rats demonstrates that neonatal muscle contains lower activities of citrate synthase and cytochrome oxidase, the difference between neonatal and adult oxidative capacity being greatest in skeletal muscle (Novak et al., 1972; Baldwin et al., 1978; Glatz and Veerkamp, 1982) and least in cardiac muscle (Baldwin, Cooke and Cheadle, 1977; Glatz and Veerkamp, 1982). 
In the immediate postnatal period, protein synthesis is sufficiently active, such that in the rat, rates of protein deposition allow a 10-fold increase in body weight between birth and 30 days of age (Winick and Noble, 1965), more than $60 \%$ of protein synthesis occurring in cardiac and skeletal muscle (Miller, 1970). In addition to large increases in structural and contractile protein concentration in muscle, there are also increases in the capacities of the enzymes of carbohydrate metabolism, such that maximal activities of glycolytic and oxidative enzymes approach those measured in the adult by the fourth week of extrauterine development in the human neonate (Colling-Saltin, 1978b). Hypertrophy of muscle fibres causes a decrease in capillary density (Sillau and Banchero, 1977; Ripoll, Sillau and Banchero, 1979) which is partially compensated for by an increase in cellular myoglobin concentration (Wittenberg, 1970; Henquell, Odoroff and Honig, 1976).

\section{Carbohydrate metabolism by muscle.}

Development of the capacity for glucose utilization in muscles. - A number of studies conducted in vitro have investigated whether glucose utilisation by cardiac and skeletal muscle changes during development. The general conclusion of such studies is that the capacity for glucose utilisation decreases with age (Goodman and Ruderman, 1979; Goodman et al., 1983).

The methodology used in these experiments involves in vitro determination of glucose utilisation rates by measuring the accumulation of metabolic endproducts (e.g. lactate, $\mathrm{CO}_{2}$, glycogen) or introduction of a non-metabolizable analogue of glucose (e.g. 2-deoxyglucose, 3-O-methylglucose) in muscle preparations such as the isolated, perfused heart, the perfused hindquarter or incubated, isolated muscle preparations (Goldberg. Martel and Kushmerick, 1975) where glucose is administered as the sole metabolic substrate. Under these conditions, glucose transport is the pseudo-flux-generating step for glucose utilization (Newsholme and Crabtree, 1979). Changes in rates of glucose transport are caused by a change in the distribution of glucose transporter units between the "active " plasma membrane fraction and the "covert " microsomal transporter pool (Wardzala and Jeanrenaud, 1981). Wang (1985) has shown that basal rates of glucose transport are highest in incubated rat diaphragm prepared from animals shortly after birth, subsequently rates of glucose transport decrease by $60-70 \%$ over the first 40 days of post-natal development (fig. 1). The total pool size of glucose transporter units (sarcolemmal plus microsomal) also declines by about $60 \%$ over a similar time period (Wang, 1985).

Few studies have investigated the capacity for the metabolism of glucose distal to the transport step. Goddman et al. (1983) showed that the rate of glucose uptake by the perfused hindquarter of rats decreased by $60 \%$ between 3 and 8 weeks of age (fig. 1); however, the fraction of glucose metabolized to lactate remained constant at about $55 \%$, suggesting no changes in the relative capacities of glycolysis and other metabolic pathways (glycogen synthesis and pyruvate oxidation). 


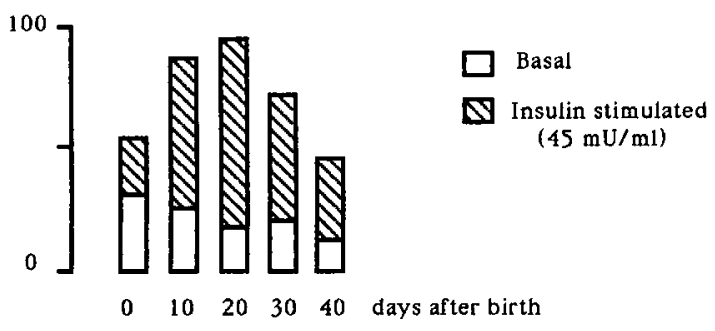

GLUCOSE TRANSPORT IN PERFUSED HINLIMB MUSCLES (Arbitrary Units)

100

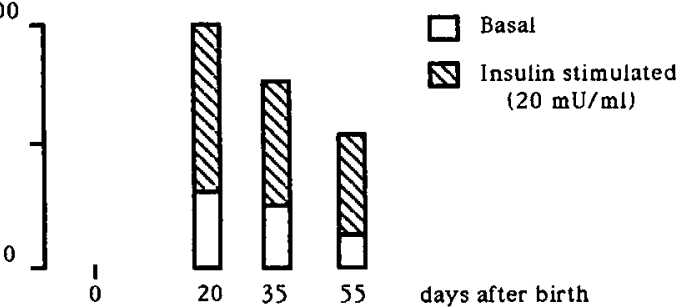

FIG. 1. - Developmental pattern of basal and insulin-stimulated glucose transport in muscles. Adapted from Wang (1985) and Goodman et al. (1983).

\section{Lipid metabolism by muscle.}

In mammals, during the suckling period, 50-70\% of the caloric intake is in the form of lipids (Ferré et al., 1986). In rats (Page, Krebs and Williamson, 1971 ; Foster and Bailey, 1976 ; Robles-Valdes, McGarry and Foster, 1976) as well as in humans (Bougnères et al., 1982, 1986), plasma triacylglycerol, free fatty acids and ketone bodies are elevated in the neonate when compared to post-weaning or adult values.

In addition to incresased lipid availibility to cardiac and skeletal muscles, the available evidence suggests that the capacity for lipid catabolism is increased in postnatal muscle. Lipoprotein lipase activity in cardiac and skeletal muscle increases markedly at birth (Cryer and Jones, 1978), enhancing the local concentration gradient of free fatty acids at the sarcolemma. The capacity of heart (Wittels and Bressler; 1965 ; Warshaw, 1972 ; Mersmann and Phinney, 1973 ; Aprille, 1976 ; Wolfe, Maxwell and Nelson, 1978 ; Werner et al., 1982, 1983) and skeletal muscle (Wolfe, Maxwell and Nelson, 1978 ; Glatz and Veerkamp, 1982 ; Caroll et al., 1983) to oxidize non-esterified fatty acids increases shortly after birth in rats, rabbits and calves. This change is paralleled by an increase in the number of mitochondria and in the activities of enzymes associated with oxidative 
metabolism of non-esterified fatty acids and specially of carnitine acyl transferase which catalyzes the mitochondrial entry of long chain fatty acyl-CoA (Wittels and Bressler, 1965; Warshaw 1972, 1974; Barrie and Harris, 1977; Glatz and Veerkamp, 1982); the increase in carnitine acyl transferase is concomittant of an increase in the tissue concentrations of carnitine (Robles-Valdes et al., 1976 ; Borum, 1978 ; Caroll et al., 1973), an essential cofactor for the enzyme (Frenkel and McGarry, 1980a. After weaning, the oxidative capacity remains high in heart (Warshaw, 1972 ; Glatz and Veerkamp, 1982 ; Werner et al., 1982) and, to a lesser extent, in skeletal muscles.

Ketone body utilisation is regulated by the blood substrate concentration and by the metabolising capacity of tissues. Whereas the capacity of the neonatal brain to utilise ketone bodies increases after birth and is higher during the postnatal period than in adult brain, the activity of specific utilising enzymes is lower in other tissues and specially in the heart (Williamson, 1982). These data suggest that in the newborn, ketone bodies could be preferentially channeled towards the brain.

\section{Integration of carbohydrate and lipid metabolism in muscle.}

4.1. The glucose/fatty acid cycle in adu/ts. - The concept of a glucose/fatty acid cycle was proposed by Randle and coworkers to explain the reciprocal relationship between the rates of oxidation of glucose and fatty acids by muscle (Randle et al., 1963). Subsequently, this concept was extended to encompass ketone body metabolism (Newsholme, 1976). Fatty acids and ketone bodies can inhibit glycolysis and glucose oxidation (Newsholme, Randle \& Manchester, 1962 ; Randle, Newsholme \& Garland, 1964); provision of acetyl-CoA from $\beta$-oxidation of fatty acids or catabolism of ketone bodies causes an increase in mitochondrial acetyl-CoA/CoASH and NAD/NADH ratios which inhibits pyruvate dehydrogenase activity and increases phosphorylation and inactivation of pyruvate dehydrogenase (Randle et al., 1978). Furthermore, increased oxidation of ketogenic fuels causes an increase in cellular citrate concentration which potentiates ATP inhibition of 6-phosphofructokinase, inhibiting glycolysis and causing an increase in hexose-monophosphate concentration; this, in turn, inhibits glucose phosphorylation by hexokinase and may increase glycogen synthesis by allosteric activation of glycogen synthase (see Randle, 1981 for review).

Lipid-derived substrate oxidation affects glucose utilisation in adult mammalian cardiac muscle (Newsholme, Randle \& Manchester, 1962; Randle, Newsholme \& Garland, 1964 ; Kauppinen, Hiltunen \& Hassinen, 1982) ; its operation and quantitative importance in overall glucose homeostasis in skeletal muscle in vivo is more controversial (Ruderman et al., 1980 ; Zorzano et al., 1985) although it has been demonstrated recently that a $48 \mathrm{~h}$-fast induced a $80 \%$ decrease of glucose utilisation in oxidative muscle in awake rats (Issad et al., 1987a).

4.2. Decreased glucose oxidation induced by lipid-derived substrates. — In neonatal skeletal muscle, it is likely that the increased availibility of fatty acids and ketone bodies and the enhanced capacities of the pathways of fatty acid and 
ketone body utilization cause increases in acetyl-CoA/CoASH and NADH/NAD ratios and inhibition of pyruvate oxidation. Although no direct evidence for an operative muscle glucose/fatty acid/ketone body cycle is available, it has been shown in the suckling newborn rat that lipid oxidation decreases glucose oxidation by inactivating pyruvate dehydrogenase (Pégorier et al., 1978, 1983) and thus increases lactate production from glucose. A similar mechanism has been postulated in the human newborn oxidizing ketone bodies (Bougnères et al., 1983). In studies using $\left[1-{ }^{13} \mathrm{C}\right]$ glucose infusion and indirect calorimetry to assess glucose metabolism in the 2 day-old human neonate fasted for $4-8 \mathrm{~h}$, Denne and Kahlan (1986) found that the glucose oxidation rate was $2.67 \pm 0.34 \mathrm{mg} \cdot \mathrm{Kg}^{-1} \cdot \mathrm{min}^{-1}$ and glucose recycling occurred at a rate of of $1.87 \pm$ $0.74 \mathrm{mg} \cdot \mathrm{Kg}^{-1} \cdot \mathrm{min}^{-1}$, suggesting a significant production of lactate, with skeletal muscle potentially making the most important contribution.

\subsection{Decreased g/ucose uptake induced by lipid-derived substrates.}

Theoretically, glycolysis and thus glucose uptake could be inhibited in neonatal muscle as demonstrated in adult muscle. In newborn rats compared at similar blood glucose concentrations, the availibility of lipid-derived substrates decreases overall glucose utilization by $30 \%$ (Ferré, Turlan \& Girard, 1985). Since muscles represent an appreciable part of the tissues metabolizing glucose, it is likely that they are involved in this phenomenon.

When measuring in vivo the basal rate of glucose utilization by using the 2-deoxyglucose technique (Ferré et al., 1985), it can be shown that this utilization is lower in soleus muscle, diaphragm and heart when compared to weaned or adult animals (Issad, Coupé, Pastor-Anglada, Ferré \& Girard, unpublished results).

Clearly, further work is necessary to assess the quantitative significance of the glucose-fatty acid cycle in muscle and its contribution to glucose homeostasis in the neonatal period, specially in the human species.

\section{Hormonal regulation of muscle metabolism.}

Many hormones interact with specific receptors in skeletal muscle including insulin, catecholamines, glucocorticoids and thyroid hormones. Our understanding of how these hormones might regulate and coordinate metabolism in the neonate is again largely drawn by extrapolation from studies performed in adult animals. On the other hand, plasma hormone profiles for animals during the period from late gestation through the postnatal period are available (Girard et al., 1977 ; Kaplan, 1981 ; Sperling, 1983; Katz, Boland \& Schmidt, 1985 ; Abuid, Stinson \& Larson, 1973).

At birth, plasma catecholamines increase acutely causing substrate mobilization through hepatic and muscle glycogenolysis and adipose tissue lipolysis, ensuring a ready substrate supply post-partum until suckling begins (Girard \& Ferré, 1982). The glucagon/insulin ratio remains high throughout the suckling period and an active gluconeogenesis and ketogenesis are maintained (Girard et 
al., 1973 ; Serpling et al., 1974 ; Girard et al., 1977). Circulating peripheral insulin concentrations are similar to those seen in fasting adult animals, increasing towards adult levels at weaning (Girard et al., 1977).

Thus, fuel availibility and hormone balance in the blood favour the limitation of glucose utilization by skeletal muscle, despite the normal or elevated capacity of neonatal muscle for glucose transport determined in vitro (Goodman et al., 1983; Wang, 1985).

Furthermore, the sensitivity and responsiveness of skeletal muscle to insulin may change during development. Recent studies by Issad et al. (1987b) have shown that higher concentrations of plasma insulin are required to suppress rates of hepatic glucose production and stimulate peripheral glucose utilization, suggesting that an insulin-resistant state exists in the suckling rat which disappears after weaning; on the other hand, Wang $(1985,1986)$ (fig. 1) has shown that insulin-stimulated glucose transport in rat diaphragm was low at birth and reached a maximum around the weaning period. This phenomenon was not related to a decrease in the intracellular pool of glucose transporter nor to a decrease in the tyrosine kinase activity of the insulin receptor, suggesting that during the suckling period an intrinsic defect in translocation of glucose transporters exists.

In vitro studies (fig. 1) (Goodman et al., 1983; Wang, 1985), as well as the comparison of in vivo effects of insulin on glucose utilization in various muscles in weaned or adult rats (Pénicaud et al., 1987), suggest that insulin sensitivity and responsiveness decrease with age between weaning and adulthood.

In summary, insulin effect on glucose utilization by muscles is low at birth, reaches a peak at weaning and then decreases with age. The underlying mechanisms are still poorly understood.

$13^{e}$ Réunion du groupe Développement I.N.R.A. Cap d'Agde, 25-27 mai 1987.

Résumé. Métabolisme glucidique et lipidique dans le muscle au cours du développement.

La masse musculaire est un organe quantitativement important en ce qui concerne l'utilisation des substrats énergétiques glucidiques et lipidiques.

Le nouveau-né doit fournir de fortes quantités d'énergie à ses muscles afin d'assurer une croissance rapide. Cependant, pendant la période néonatale, le nouveau-né est nourri avec un régime riche en lipides et pauvre en glucides, le lait. II doit donc également épargner du glucose pour les organes tel que le cerveau qui sont des utilisateurs obligatoires de ce substrat. La régulation du métabolisme énergétique dans les muscles revêt donc une extrême importance pour l'homéostasie métabolique postnatale.

Chez l'homme, on peut à la naissance classer les fibres musculaires d'un point de vue histochimique en catégories semblables à celles observées chez l'adulte. Leurs proportions respectives sont d'ailleurs assez semblables chez le nouveau-né et chez l'adulte. Cependant, les activités maximales des enzymes de la glycolyse et du métabolisme oxydatif sont plus faibles que chez l'adulte.

Chez le rat, la capacité des muscles à utiliser le glucose est faible à la naissance, maximale au moment du sevrage puis diminue avec l'âge. Pendant la période d'allaitement, les concentrations circulantes des substrats énergétiques dérivés des lipides sont élevées 
de même que les capacités musculaires pour leur oxidation; de plus, la concentration plasmatique d'insuline est faible pendant l'allaitement et la sensibilité à l'insuline réduite. Tous ces facteurs concourent à limiter l'utilisation de glucose dans les muscles pendant la période néonatale.

\section{References}

ABUID J., STINSON A., LARSON P. R., 1973. Serum triiodothyronine and thyroxine in the neonate and acute increase in these hormones following delivery. J. clin. Invest., 52, 1195-2001.

ADAM P. A. J., RAIHA N., RAHIALA E. L., KEKOMAKI M., 1975. Oxidation of glucose and D-B-hydroxybutyrate by the early human fetal brain. Acta pediatr. scand., 64, 1.7-24.

APRILLE J. R., 1976. Dietary lipid and postnatal development. II. Palmityl Coenzyme A oxidation in heart and liver. Pediatr. Res., 10, 982-985.

BALDWIN K. M., COOKE D. A, CHEADLEW. G, 1977. Enzyme alterations in neonatal heart muscle during development. J. mol. cell Cardiol., 9, 651-660.

BALDWIN K. M., HOOKER K. M., CAMPBELL P. J., LEWIS R. E., 1978. Enzyme changes in neonatal skeletal muscle : effect of thyroid deficiency. Am. J. Physiol., 235, C97-C102.

BARRIE S. E., HARRIS P., 1977. Myocardial enzyme activities in guinea pigs during development. Am. J. Physiol., 233, H707-H710.

BIER D. M., LEAKE R. D., HAYMOND M. W., ARNOLD K. J., GRUENKE L. D., SPERLING M. A., KIPNIS D. M., 1977. Measurement of "true" glucose production rates in infancy and childhood with 6,6-dideuteroglucose. Diabetes, 26, 1016-1023.

BORUM P. R., 1978. Variation in tissue carnitine concentration with age and sex in the rat. Biochem. J., 176, 677-681.

BOUGNĖRES P., FERRE P., CHAUSSAIN J. L., JOB J. C., 1983. Glucose metabolism in hyperinsulinemic infants : the effects of fasting and sodium- $D, L$ hydroxybutyrate on glucose production and utilization. J. clin. Endocrin. Met., 57, 1054-1060.

BOUGNËRES P. F., KARL I. E., HILLMAN L. S., BIER D. M., 1982. Lipid transport in the human newborn. Palmitate and glycerol turnover and the contribution of glycerol to neonatal hepatic glucose output. J. clin. Invest., 70, 262-270.

BOUGNĖRES P. F., LEMMEL C., FERRÉ P., BIER D. M., 1986. Ketone body transport in the human neonate and infant. J. clin. Invest., 77, 42-48.

BROOKE M. H., KAISER K. K., 1970. Muscle fibre-types : how many and what kind. Arch. Neurol., 23, 369-379.

CARROLL J. E., SHUMATE J. B., VILLADIEGO A., CHOKSI R. M., MORSE D. P., 1983 . Skeletal muscle fatty acid oxidation during early postnatal development in the rat. Biol. Neonate, $\mathbf{4 3}$, $191-197$.

COLLING-SALTIN A. S.., 1978a. Enzyme histochemistry on skeletal muscle of the human fetus. J. neurol. Sci, 39, 169-185.

COLLING-SALTIN A. S., 1978b. Some quantitative biochemical evaluations of developing skeletal muscles in the human fetus. J. neurol. Sci. 39, 187-198.

CRYER A., JONES H. M., 1978. Developmental changes in the activity of lipoprotein lipase in rat lung, cardiac muscle, skeletal muscle and brown adipose tissue. Biochem. J., 174, 447-451.

DE FRONZO R. A., JACOT E., JEOUIER E., MAEDER E., WAHREN J., FELBER J. P., 1981. The effect of insulin on the disposal of intravenous glucose. Results from indirect calorimetry and hepatic and femoral venous catheterization. Diabetes, 30, 1000-1007.

DENNE S. C., KALHAN S. C., 1986. Glucose carbon recycling and oxidation in human newborns. Am. J. Physiol., 251, E71-E77.

DOBBING J., SANDS J., 1973. Quantitative growth and development of human brain. Arch. Dis. Child., 48, 757-767.

FERRE P., DECAUX J. F., ISSAD T., GIRARD J. R., 1986. Changes in energy metabolism during the suckling and weaning period in the newborn. Reprod. Nutr. Dévelop., 26, 619-631. 
FERRE P., LETURQUe A., BURNOL A. F., PENICAUD L., GIRARD J. R., 1985. A method to quantify glucose utilization in vivo in skeletal muscle and white adipose tissue of the anaesthetized rat. Biochem. J., 228, 103-110.

FERRE P., TURLAN P., GIRARD J., 1985 . Effects of medium chain triglyceride feeding or glucose infusion on glucose kinetics in the newborn rat. J. develop. Physiol., 7, 35-46.

FOSTER P. C., BAILEY E., 1976. Changes in the activities of the enzymes of hepatic fatty acid oxidation during development of the rat. Biochem. J., 154, 49-56.

FRENKEL R. A., McGARRY J. D., 1980. Carnitine biosynthesis, metabolism and functions, Acad. Press, New York.

GIRARD J. R., CUENDET G. S., MARLISS E. B., KERVRAN A., RIEUTORT M., ASSAN R., 1973. Fuels, hormones and liver metabolism at term and during the early postnatal period in the rat. J. clin. Invest., 52, 3190-3200.

GIRARD J. R., FERRÉ P., 1982. Metabolic and hormonal changes around birth, 517-551. In JONES C. T., Biochemical development of the fetus and neonate, Elsevier, Amsterdam.

GIRARD J. R., FERRE P., KERVRAN A, PEGORIER J. P., ASSAN R., 1977. Role of the insulin/glucagon ratio in the changes of hepatic metabolism during development of the rat, 563-581. In FOA P. P., BAJAJ J. S., FOA N. L., Glucagon : its role in physiology and clinical medicine, Springer Verlag, New York.

GLATZ J. F. C., VEERKAMP J. H.., 1982. Postnatal development of palmitate oxidation and mitochondrial enzyme activities in rat cardiac and skeletal muscle. Biochim. Biophys. Acta, 711, 327-335.

GOLDBERG A. L., MARTEL S. B., KUSHMERICK M. J., 1975. In vivo preparations of the diaphragm and other skeletal muscles. Method. Enzymol., 39, 82-94.

GOLDSPINK G., 1970. Morphological adaptation due to growth and activity, 521-536. In BIRSKY J., CASSENS R. G., MARSH B. B., Physiology and biochemistry of muscle as food, Univ. Wisconsin Press, Madison.

GOODMAN M. N., RUDERMAN N. B., 1979. Insulin sensitivity of rat skeletal muscle : effects of starvation and aging. Am. J. Physiol., 236, E519-E523.

GOODMAN M. N., DLUZ S. M., McELANEY M. A., BELUR E., RUDERMAN N. B., 1983. Glucose uptake and insulin sensitivity in rat muscle: changes during 3-96 weeks of age. $A m$. J. Physiol., 244, E93-E100.

HENQUELL L., ODOROFF C. L., HONIG C. R., 1976. Coronary intercapillary distance during growth : relation to $\mathrm{pO}_{2}$ and aerobic capacity. Am. J. Physiol., 231, 1852-1859.

ISSAD T., PÉNICAUD L., FERRÉ P., KANDE J., BAUDON M. A., GIRARD J. R., 1987a. Effects of fasting on tissue glucose utilization in conscious, resting rats. Major glucose-sparing effect in working muscles. Biochem. J., 246, 241-244.

ISSAD T., COUPE C., FERRÉ P., GIRARD J., 1987b. Insulin resistance during suckling period in rats. Am. J. Physiol., 253, E142-E148.

KALHAN S. C., SAVIN S. M., ADAM P. A. J., 1976. Measurement of glucose turnover inthe human newborn with $\left[1-{ }^{13} \mathrm{C}\right]$ glucose. J. clin. Endocrinol. Metab., 43, 704-707.

KAPLAN S. A., 1981. The insulin receptor. Pediatr. Res., 15, 1156-1162.

KATZ M. S., BOLAND S. R., SCHMIDT S. J., 1985. Developmental changes of B-adrenergic receptor-linked adenylate cyclase of rat liver. Am. J. Physiol., 248, E712-E718.

KAUPPINEN R. A., HILTUNEN J. K., HASSINEN I. E., 1982. Comparmentation of citrate in relation to the regulation of glycolysis and the mitochondrial transmembrane proton electrochemical potential gradient in isolated perfused rat heart. Biochim. Biophys. Acta, 681, 286-291.

KRAUS H., SCHLENKER S., SCHWEDESKY D., 1974. Development changes of cerebral ketone body utilization in human infants. Hoppe Sey/er's Z. Physiol. Chem., 335, 164-170.

MERSMANN H. J., PHINNEY G., 1973. In vivo fatty acid oxidation in liver and heart from neonatal swine (Sus domesticus). Comp. Biochem. Physiol., 44B, 219-223.

MILLER S. A., 1970. Nutrition in the neonatal development of protein metabolism. Fed. Proc., 29, 1497-1502.

NEWSHOLME E. A., 1976. Carbohydrate metabolism in vivo: regulation of blood glucose level. Clin. Endocrinol. Metab., 5, 543-578. 
NEWSHOLME E. A., CRABTREE B., 1979. Theoretical principles in the approaches to the control of metabolic pathways and their application to glycolysis in muscle. J. mol. cel/ Cardiol., 11 , 839-856.

NEWSHOLME E. A., RANDLE P. J., MANCHESTER K. L., 1962. Inhibition of 6-phosphofructokinase reaction in perfused rat heart by respiration of ketone bodies, fatty acids and pyruvate. Nature (London), 193, 270-271.

NOVAK E., DRUMMOND G. 1., SKALA J., HAHN P., 1972. Developmental changes in cyclic AMP, protein kinase, phosphorylase kinase and phosphorylase in liver, heart and skeletal muscle of the rat. Arch. Biochem. Biophys., 150, 511-518.

PAGE A., KREBS H. A., WILLIAMSON D. H., 1971. Activities of enzymes of ketone body utilization in brain and other tissues of suckling rats. Biochem. J., 121, 49-53.

PATEL M. S., JOHNSON C. A., RAJAN R., OWEN O. E., 1975. The metabolism of ketone bodies in developing human brain; development of ketone body utilizing enzymes and ketone bodies as precursors for lipid synthesis. J. Neurochem., 25, 905-913.

PEGORIER J. P., FERRE P., LETURQUE A., GIRARD J., 1978. The metabolic effects of sodium dichloroacetate in the suckling newborn rats. Diabetologia, 15, 459-463.

PÉGORIER J. P., LETURQUE A., FERRÉ P., TURLAN P., GIRARD J. R., 1983. Effects of medium chain triglyceride feeding on glucose homeostasis in the newborn rat. Am. J. Physiol., 244, E239-E334.

PÉNICAUD L., FERRÉ P., TERRETAZ J., KINEBANYAN M. F., LETURQUE A., DORE E., GIRARD J., JEANRENAUD B., PICON L., 1987. Development of obesity in Zucker rats : early insulin resistance in muscles but normal sensitivity in white adipose tissue. Diabetes, 36, 626-631.

RANDLE P. J., 1981. Molecular mechanisms regulating fuel selection in muscle, 13-32. In POORTMANS J., NISET G., Biochemistry of exercise, Vol. IV-A, Univ. Park Press, Baltimore.

RANDLE P. J., GARLAND P. B., HALES C. N., NEWSHOLME E. A., 1963. The glucose/fatty acid cycle. Its role in insulin sensitivity and the metabolic disturbances of diabetes mellitus. Lancet, I, 785-789.

RANDLE P. J., NEWSHOLME E. A., GARLAND P. B., 1964. Effects of fatty acids, ketone bodies and pyruvate and of alloxan-diabetes and starvation on the uptake and metabolic fate of glucose in rat heart and diaphragm muscles. Biochem. J., 93, 652-665.

RANDLE P. J., SUGDEN P. H., KERBEY A. L., RADCLIFFE P. M., HUTSON N. J., 1978 . Regulation of pyruvate oxidation and the conservation of glucose. Biochem. Soc. Symp., 43, 47-67.

ROBLES-VALDES G., McGARRY J. D., FOSTER D. W., 1976. Maternal fetal carnitine relationships and neonatal ketosis in the rat. J. biol. Chem., 251, 6007-6012.

RIPOLL E., SILLAU A. H., BANCHERO N., 1979. Changes in the capillarity of skeletal muscle in the growing rat. Pflügers Arch., 380, 153-158.

RUDERMAN N. B., KEMMER F. W., GOODMAN M. N., BERGER M., 1980. Oxygen consumption in perfused skeletal muscle. Biochem. J., 190, 57-64.

SETTERGREN G., LINDBLAD B. S., PERSSON B., 1976. Cerebral blood flow and exchange of oxygen glucose, ketone bodies, lactate, pyruvate and amino acids in infants. Acta pediatr. scand., 65, 343-353.

SILLAU A. H., BANCHERO N., 1977. Effect of maturation on capillary density, fibre size and composition in rat skeletal muscle. Proc. Soc. exp. Biol. Med., 154, 461-466.

SPERLING M. A., 1983. Integration of fuel homeostasis by insulin and glucagon in the newborn. Monographs in Pediatrics, 16, 39-58.

SPERLING M. A., DELAMATER P. V., PHELPS D., FISER R., FISHER D. A., 1974. Spontaneous and amino acid stimulated glucagon secretion in the immediate postnatal period: relation to glucose and insulin. J. clin. Invest., 53, 1159-1166.

TOMANEK R. J., COLLING-SALTIN A. S., 1977. Cytological differentiation of human fetal skeletal muscle. Am. J. Anat., 149, 227-246.

WANG C., 1985. Insulin-stimulated glucose uptake in rat diaphragm during postnatal development : lack of correlation with the number of insulin receptors and of intracellular glucose transporters. Proc. nat. Acad. Sci. USA, 82, $3621-3625$.

WANG C., 1986. Purification and autophosphorylation of insulin receptors from rat skeletal muscle. Biochim. Biophys. Acta, 888, 107-115. 
WARSHAW J. B., 1972. Cellular energy metabolism during fetal development. IV. Fatty acid activation, acyl transfer and fatty acid oxidation during development of the chick and rat. Dev. Biol., 28, 537-544.

WARSHAW J. B., 1974. Fatty acid oxidation during development, 88-97. In H. H. BODE, J. B. WARSHAW, Parenta/ nutrition in infancy and chilhood, Plenum Publ. Corp., N.Y.

WARDZALA L. J., JEANRENAUD B., 1981. Potential mechanism of insulin action on glucose transport in the isolated rat diaphragm. J. biol. Chem., 256, 7090-7093.

WERNER J. C., WHITMAN V., MUSSELMAN J., SCHULER H. G., 1982. Perinatal changes in mitochondrial respiration of the rabbit heart. Biol. Neonate, 42, 208-216.

WERNER J. C., WHITMAN V., VARY T. C., FRIPP R. R., MUSSELMAN J., SCHULER H. G., 1983. Fatty acid and glucose utilization in isolated working newborn pig hearts. $A m$. $J$. Physiol., 244, E19-E23.

WILLIAMSON D. H., 1982. The production and utilization of ketone bodies in the neonate, 621-650. In C. T. JONES, Biochemical development of the fetus and neonate, Elsevier, Amsterdam.

WINICK M., NOBLE A., 1965. Quantitative changes in DNA, RNA and protein during prenatal and postnatal growth in the rat. Dev. Biol., 12, 451-466.

WITTELS B., BRESSLER R., 1965. Lipid metabolism in the newborn heart. J. clin. Invest., 44. 1639-1646.

WITTENBERG J. B.., 1970. Myoglobin-facilitated oxygen diffusion : role of myoglobin in oxygen entry into muscle. Physiol. Rev., 50, 559-636.

WOLFE R. G., MAXWELL C. V., NELSON E. C., 1978. Effect of age and dietary fat level on fatty acid oxidation in the neonatal pig. J. Nutr., 108, 1621-1634

ZORZANO A., BALON T. W., BRADY L. J., RIVERA P., GARETTO L. P., YOUNG J. C., GOODMAN M. N., RUDERMAN N. B., 1985. Effects of starvation and exercice on concentrations of citrate, hexose phosphates and glycogen in skeletal muscle and heart. Biochem. J., 232, 585-591. 